\title{
KAJIAN KARAKTERISTIK PURE KERING UBI JALAR DENGAN PERLAKUAN SUHU DAN LAMA ANNEALING SEBAGAI SEDIAAN PANGAN DARURAT
}

\author{
M. Sunyoto ${ }^{1}$, R. Andoyo ${ }^{2}$, H. Radiani A. ${ }^{3}$, Rista. $N^{4}$ \\ 1,2,3,4Jurusan Teknologi Pangan, Fakultas Teknologi Industri Pertanian, \\ Universitas Padjadjaran \\ Jatinangor, Indonesia \\ e-mail: emhaer@yahoo.co.id ; robitpn@yahoo.com ; henifien@yahoo.com; \\ rista_nurmalinda@yahoo.com
}

\begin{abstract}
Abstrak
Klon ubi jalar unggulan Awachy 5 memiliki kandungan pati tinggi dan ketahanan hama yang lebih baik dibandingkan ubi jalar lokal. Namun pengolahan menjadi pure kering dengan suhu tinggi mengakibatkan kerusakan granula pati karena kurang stabil terhadap pemanasan sehingga tekstur produk menjadi lengket. Masalah ini dapat diperbaiki melalui proses modifikasi annealing. Penelitian ini bertujuan untuk mendapatkan perlakuan suhu dan lama annealing yang dapat menghasilkan pure kering ubi jalar dengan karakteristik terbaik. Metode penelitian yang digunakan yaitu metode eksperimental dengan Rancangan Acak Kelompok (RAK) yang terdiri dari 5 perlakuan dengan 3 ulangan, yaitu kontrol, annealing $40^{\circ} \mathrm{C}$ selama 4 jam; $40{ }^{\circ} \mathrm{C}$, 8 jam; $50^{\circ} \mathrm{C}, 4$ jam; dan $50^{\circ} \mathrm{C}, 8$ jam. Hasil penelitian menunjukan bahwa pure kering ubi jalar dengan perlakuan annealing $50{ }^{\circ} \mathrm{C}$ selama 4 jam menghasilkan karakteristik terbaik dengan kadar air 4,88\%; suhu awal gelatinisasi $54,30{ }^{\circ} \mathrm{C}$; viskositas puncak $850,5 \mathrm{cP}$; viskositas breakdown 29,37 cP; viskositas setback $395 \mathrm{cP}$; hardness 108,54 gf; adhesiveness -69,774 gf; kesukaan panelis terhadap warna 3,311; daya rehidrasi 3,216 $\mathrm{mL} / \mathrm{g}$, rendemen sebesar $23,11 \%$, serta memiliki kandungan protein $1,76 \%$; lemak 1,89\%; abu 0,76\%; dan karbohidrat 90,88\%. Karakteristik tersebut menunjukan bahwa pure kering dapat menjadi sediaan pangan darurat dalam bentuk basah dan semi basah sepertisup dan produk siap konsumsi dengan direhidrasi.
\end{abstract}

Kata kunci : Annealing, Awachy 5, Pure Kering Ubi Jalar

\begin{abstract}
Featured sweet potato clones of Awachy 5, has a higher starch content and a better pest resistance than the local sweet potato. High temperature used in the processing of dried sweet potato puree causes the damage on the starch granules due to less stable to heat, causing an impact of sticky texture. This problem can be corrected through the process of annealing modification. The aim of this study was to obtain temperature treatment and annealing duration that produce dried sweet potato puree with optimum characteristics. The research method was a randomized block design, consisting of 5 treatments with 3 replications: control, annealing $40{ }^{\circ} \mathrm{C}$ for 4 hours; $40^{\circ} \mathrm{C}, 8$ hours; $50{ }^{\circ} \mathrm{C}, 4$ hours; and 50 ${ }^{\circ} \mathrm{C}$, 8 hours. The results showed that dried sweet potato puree with annealing treatment of $50{ }^{\circ} \mathrm{C}$ for 4 hours produced the best characteristics with a water content of $4.88 \%$, the initial temperature of gelatinization $54.30{ }^{\circ} \mathrm{C}$; peak viscosity $850.5 \mathrm{cP}$; viscosity breakdown $29.37 \mathrm{cP}$; viscosity setback $395 \mathrm{cP}$; hardness $108.54 \mathrm{gF}$; adhesiveness $69.774 \mathrm{gF}$; panelists preference to color 3.311 ; rehydration power $3.216 \mathrm{~mL} / \mathrm{g}$; yield of $23.11 \%$; and having a protein content of $1.76 \%$; $1.89 \%$ fat; ash $0.76 \%$; and $90.88 \%$ carbohydrate. The characteristics showed that dried puree could become an emergency food in the form of wet and semi-wet, like soup and a product ready for consumption through rehydration.
\end{abstract}

Keywords: Annealing, Awachy 5, Dried Sweet Potato Puree. 


\section{PENDAHULUAN}

Pure merupakan bahan makanan yang dilembutkan (Kamus Besar Bahasa Indonesia, 1996). Mashed adalah salah satu jenis produk pure yang dibuat dengan memberi perlakuan panas pada bahan dan menumbuk bahan dalam keadaan panas hingga menjadi halus (Nahari, 2016). Ubi jalar dengan kandungan pati yang tinggi, mengandung serat dan beberapa mineral berpotensi digunakan sebagai bahan baku pembuatan pure kering. Produk hancuran ubi jalar seperti pure ubi jalar merupakan salah satu olahan ubi jalar yang banyak berkembang di negara maju. Pengolahan ubi jalar menjadi pure berpotensi untuk dikembangkan mengingat pemanfaatannya yang cukup luas seperti dapat digunakan sebagai bahan pencampur berbagai produk pangan lainnya seperti es krim, roti serta berbagai kue (Santoso, 2010). Namun demikian pembuatan pure dinilai kurang praktis. Disisi lain, kadar air pure yang tinggi menyebabkan umur simpan produk yang relatif sebentar.

Produk dengan kadar air yang tinggi dapat dikeringkan untuk meningkatkan umur simpan produk. Pure dikeringkan dapat menghasilkan produk instan, yaitu produk yang dapat dikonsumsi langsung dengan menambahkan air panas atau dengan pengukusan sebentar dan mempunyai umur simpan yang lama (Santoso, 2010). Produk pangan instan yang memiliki umur simpan yang panjang berpotensi untuk dikembangkan menjadi emergency food product.

Karakteristik yang menjadi prioritas dalam pengembangan produk pangan darurat menurut Zoumas, dkk (2002), yaitu aman, memiliki palabilitas yang baik, mudah didistribusikan, mudah dikonsumsi, dan memiliki kalori yang tinggi. Karaketristik mudah dikonsumsi dan didistribusikan dapat dilakukan dengan melakukan proses pengeringan pada pure ubi jalar.

Proses pengolahan dan pengeringan pure ubi jalar dilakukan dengan menggunakan suhu tinggi. Proses pengolahan produk pure dengan suhu tinggi menyebabkan tekstur produk setelah

rehidrasi yang lengket dan kurang disukai akibat banyaknya granula pati yang rusak selama pengolahan karena sifat alami pati yang tidak tahan panas. Sifat alami pati yang membentuk viskositas tidak seragam, tidak tahan terhadap pemanasan suhu tinggi, asam dan proses mekanis dan memiliki kelarutan yang terbatas di dalam air (Kusnandar, 2010) dapat menghambat dalam pengolahan pangan, salah satunya yaitu pada produk pure atau mashed ubi jalar.

Sifat alami pati dapat dimodifikasi dengan berbagai metode, diantaranya modifikasi fisik, kimia, dan enzimatis untuk memperbaiki sifat alami pati serta dapat menghasilkan pati dengan sifat yang dikehendaki (Koswara, 2009). Modifikasi fisik seperti modifikasi annealing merupakan salah satu metode yang dirasa aman karena tidak meninggalkan residu bahan kimia. Modifikasi hydrothermal annealing merupakan perlakuan fisik terhadap granula pati dengan air berlebih pada suhu dibawah suhu gelatinisasi pada waktu yang telah ditentukan (Hoover dan Vasanthan 1994 dikutip Oktavianti dan putri, 2015). Perlakuan annealing yang dilakukan pada bahan dalam bentuk chips dianggap lebih sederhana dan mudah diaplikasikan pada industri pangan. Keunggulan dari tepung atau pati termodifikasi annealing yang dihasilkan yaitu mampu meningkatkan suhu gelatinisasi dan menghasilkan pati yang lebih stabil terhadap panas, sehingga karakteristik fisik dan kimia pati dalam tepung ubi jalar menjadi lebih optimal dan dapat digunakan sebagai bahan baku untuk bermacam-macam produk olahan pangan (Oktavianti dan Putri, 2015).

Modifikasi hidrotermal seperti annealing dipengaruhi oleh suhu dan waktu proses perendamannya karena dapat mempengaruhi kemampuan penetrasi serta gugus amorf pada pati (Gomes, dkk, 2004 dikutip Salim dan Putri, 2015). Berdasarkan pertimbangan tersebut, maka perlu diketahui pengaruh penggunaan suhu dan lama perendaman annealing terhadap karakteristik pure kering ubi jalar yang dihasilkan.

\section{MATERI DAN METODE}

Bahan yang digunakan pada penelitian iniyaitu ubi jalar klon Unpad varietas Awachy 5 dengan umur panen 4-4,5 bulan yang diperoleh dari Kecamatan Teluk Jambe- 
Karawang Barat. Bahan lainnya adalah senyawa kimia sebagai bahan pakai habis untuk analisis laboratorium.

Peralatan laboratorium yang digunakan selain peralatan baku juga Rapid Visco Analyzer juga Texture Analyzer. Proses pembuatan pure kering ubi jalar dengan perlakuan annealing mengacu pada penelitian Salim dan Putri (2015) serta penelitian Nahari (2016) yang dapat dilihat pada Gambar 1.

Metode yang digunakan dalam penelitian kali ini yaitu metode eksperimental menggunakan RAK. Percobaan terdiri dari 5 perlakuan yang terdiri dari kombinasi variasi 2 suhu annealing serta 2 lama annealing yang dilakukan pada kadar air berlebih (>65\%). Masing-masing perlakuan dilakukan pengulangan sebanyak 3 kali sehingga diperoleh 15 satuan percobaan. Adapun perlakuan yang dicoba adalah sebagai berikut:

$A=$ Tanpa perlakuan (Kontrol)

$\mathrm{B}=$ Suhu annealing $40^{\circ} \mathrm{C}$ selama 4 jam

$\mathrm{C}=$ Suhu annealing $40^{\circ} \mathrm{C}$ selama 8 jam

$\mathrm{D}=$ Suhu annealing $50^{\circ} \mathrm{C}$ selama 4 jam

$\mathrm{E}=$ Suhu annealing $50^{\circ} \mathrm{C}$ selama 8 jam

Kombinasi perlakuan suhu dan lama annealing mengacu pada penelitian sebelumnya yang dilakukan oleh Salim dan Putri (2015), Oktavianti dan Putri (2015), Putri dan Zubaidah (2015) serta beberapa penelitian lainnya. Pemilihan perlakuan tersebut juga didasarkan pada perlakuan pendahuluan yang menunjukan bahwa perlakuan annealing lebih dari 8 jam pada pembuatan pure kering ubi jalar menghasilkan karakteristik organoleptik yang kurang baik dan kurang disukai panelis. Proses pembuatan pure kering Ubi jalar dengan perlakuan Annealing disajikan dalam Gambar 1.

Uji pada taraf $5 \%$ digunakan untuk mengetahui ada tidaknya keragaman antar perlakuan, jika $\mathrm{Fh} \leq \mathrm{F}_{0,05}$ maka dinyatakan tidak ada keragaman antar perlakuan, sedangkan jika $\mathrm{Fh}>\mathrm{F}_{0,05}$, maka dinyatakan ada keragaman antar perlakuan, selanjutnya dilakukan pengujian lanjutan berupa Uji Beda Jarak Berganda Duncan pada taraf $5 \%$ (LSR Test) untuk mengetahui beda pengaruh antar perlakuan.

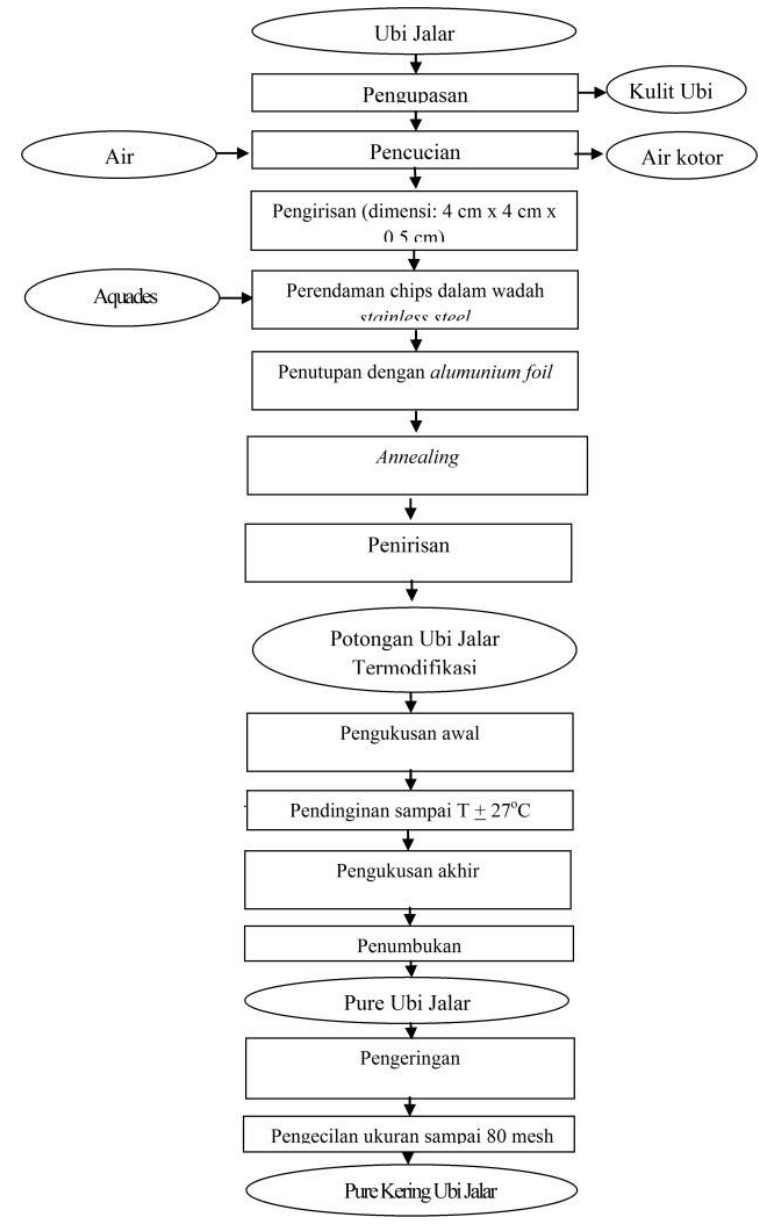

Gambar 1. Diagram Proses Pembuatan Pure Kering Ubi jalar dengan Perlakuan Annealing

(Salim dan Putri (2015) dan Nahari (2016))

\section{HASIL DAN PEMBAHASAN Sifat Amilografi}

Sifat amilografi pure kering ubi jalar yang diamati pada penelitian ini meliputi suhu awal gelatinisasi, viskositas puncak, viskositas breakdown, dan viskositas setback. Data sifat amilografi pure kering ubi jalar dapat dilihat pada Tabel 1. 
Tabel 1. Pengaruh Annealing terhadap Sifat Amilografi Pure Kering Ubi jalar

\begin{tabular}{ccccc}
\hline Perlakuan & \multicolumn{4}{c}{ Sifat Amilografi } \\
\cline { 2 - 5 } Annealing & SAG $\left({ }^{\circ} \mathrm{C}\right)$ & \multicolumn{1}{c}{ VP $(\mathrm{cP})$} & VB $(\mathrm{cP})$ & VS $(\mathrm{cP})$ \\
\hline A & $50,28 \pm 0,02 \mathrm{a}$ & $148,0 \pm 39,6 \mathrm{a}$ & $2,17 \pm 0,57 \mathrm{a}$ & $71,50 \pm 8,66 \mathrm{a}$ \\
$\mathrm{B}$ & $50,25 \pm 0,03 \mathrm{a}$ & $492,3 \pm 52 \mathrm{~b}$ & $3,50 \pm 1,80 \mathrm{a}$ & $111,50 \pm 43,25 \mathrm{a}$ \\
$\mathrm{C}$ & $50,37 \pm 0,15 \mathrm{a}$ & $770,0 \pm 150 \mathrm{c}$ & $44,50 \pm 11,3 \mathrm{~b}$ & $268,00 \pm 50,22 \mathrm{~b}$ \\
D & $54,30 \pm 3,52 \mathrm{a}$ & $850,5 \pm 214 \mathrm{c}$ & $29,67 \pm 6,52 \mathrm{c}$ & $395,00 \pm 22,42 \mathrm{c}$ \\
E & $64,66 \pm 2,34 \mathrm{~b}$ & $637,8 \pm 78 \mathrm{c}$ & $12,00 \pm 3,59 \mathrm{~d}$ & $283,00 \pm 7,55 \mathrm{bc}$ \\
\hline
\end{tabular}

Keterangan :

Rata-rata perlakuan yang ditandai dengan huruf kecil yang sama tidak berbeda nyata pada taraf 5\% menurut Uji Duncan

SAG: Suhu Awal Gelatinisasi

VP: Viskositas Puncak

VB: Viskositas Breakdown

VS: Viskositas Setback

\section{Suhu Awal Gelatinisasi}

Hasil uji statistik menunjukan bahwa pure kering ubi jalar kontrol memiliki pengaruh yang tidak berbeda nyata dengan semua perlakuan kecuali dengan perlakuan annealing pada suhu $50{ }^{\circ} \mathrm{C}$ selama 8 jam. Peningkatan suhu awal gelatinisasi ini diakibatkan karena pati pada pure kering ubi jalar yang telah termodifikasi annealing memiliki resistensi yang lebih tinggi terhadap suhu tinggi. Suhu tinggi yang digunakan selama proses modifikasi dapat meningkatkan kristalinitas pati akibat perubahan struktur granula pati (Sun, dkk., 2013).

Pati diberikan suhu tinggi $\left(40{ }^{\circ} \mathrm{C}\right.$ dan $50{ }^{\circ} \mathrm{C}$ ) namun tidak mencukupi untuk terjadinya gelatinisasi menyebabkan terjadinya pembentukan daerah kristalin baru atau terjadi reorientasi. Perubahan molekul tersebut dapat berpengaruh terhadap sifat pati, salah satunya yaitu adanya perubahan suhu gelatinisasi (Collado and Corke, 1999).

\section{Viskositas Puncak}

Berdasarkan hasil perhitungan statistik terhadap rata-rata perlakuan viskositas puncak menunjukan bahwa berbagai perlakuan suhu dan lama annealing memberikan pengaruh yang berbeda nyata terhadap viskositas puncak pure kering ubi jalar. Namun perlakuan annealing pada suhu $40^{\circ} \mathrm{C}$ selama 8 jam, $50^{\circ} \mathrm{C}$ selama 4 jam, dan $50{ }^{\circ} \mathrm{C}$ selama 8 jam menunjukan nilai yang tidak berpengaruh nyata.
Nilai viskositas puncak pure kering ubi jalar mengalami peningkatan seiring dengan meningkatnya perlakuan suhu dan lama annealing $\mathrm{Hal}$ ini disebabkan karena proses modifikasi dapat menyebabkan peningkatan rigiditas granula pati akibat gelatinisasi yang belum tercukupi sehingga mengakibatkan adanya peningkatan viskositas pasta karena granula yang rigid memiliki ketahanan pengadukan yang lebih baik (Adebowale, dkk, 2005).

Pure kering ubi jalar telah mengalami proses gelatinisasi sebelum pengeringan sehingga memiliki nilai viskositas puncak yang rendah. Penelitian Honestin (2007) juga menunjukan bahwa viskositas puncak tepung yang telah tergelatinisasi memiliki nilai yang lebih rendah dibandingkan dengan tepung yang belum tergelatinisasi. Hal ini disebabkan karena granula pati yang belum tergelatinisasi memiliki ikatan yang masih kuat sehingga pada tepung tanpa pemasakan awal masih memiliki kemampuan untuk terus membengkak hingga pembengkakan yang maksimum, sedangkan pada tepung yang sudah tergelatinisasi sebagian granula pati sudah mengalami kerusakan sehingga tidak banyak ikatan yang dapat menahan terjadinya pembengkakan granula pati. Menurut Djuwardi (2009), bahan baku dengan viskositas puncak $<500 \mathrm{BU}$ (setara dengan $<1050 \mathrm{cP}$ ) sesuai untuk produk basah, Hal tersebut menunjukan bahwa pure kering ubi jalar selain dapat dikonsumsi langsung, juga dapat diaplikasikan pada produk pangan basah seperti sup. 


\section{Viskositas Jatuh (Breakdown)}

Hasil analisis statistik menunjukan bahwa variasi perlakuan suhu dan lama annealing memberikan pengaruh yang berbeda nyata terhadap nilai viskositas jatuh pure kering ubi jalar. Perlakuan annealing dengan suhu $40^{\circ} \mathrm{C}$ selama 8 jam, perlakuan annealing dengan suhu $50^{\circ} \mathrm{C}$ selama 4 jam, dan perlakuan annealing dengan suhu $50{ }^{\circ} \mathrm{C}$ selama 8 jam menunjukan adanya kecenderungan penurunan nilai viskositas jatuh yang diakibatkan oleh adanya peningkatan stabilitas pasta pati terhadap pemanasan seiring dengan meningkatnya stabilitas granula pati (Lestari, 2009 dalam Pertiwi, 2015). Penurunan nilai viskositas jatuh pada modifikasi annealing terjadi akibat adanya proses pemanasan yang diikuti oleh proses pendinginan (perendaman) menyebabkan pembentukan struktur kristalin baru sehingga pati dapat dipertahankan (Oktavianti dan Putri, 2015).

Nilai viskositas jatuh yang rendah pada pure kering ubi jalar dikarenakan tepung sudah mengalami gelatinisasi sebelum pengeringan seperti yang terdapat pada penelitian Honestin (2007), tepung dengan pemasakan awal memiliki viskositas jatuh yang lebih rendah dibandingkan dengan tepung tanpa pemasakan awal. Tepung dengan viskositas jatuh yang rendah menunjukan kestabilan yang tinggi terhadap pemanasan dan pengadukan sehingga tepung ini baik digunakan pada pengolahan produk yang melalui proses pemanasan dan pengadukan seperti pie filling, dan sup (Honestin, 2007).

\section{Viskositas Balik (Setback)}

Hasil analisis statistik menunjukan bahwa berbagai perlakuan suhu dan lama annealing memberikan pengaruh yang nyata terhadap nilai viskositas balik. Namun, nilai viskositas balik pure kering ubi jalar dengan perlakuan annealing $40{ }^{\circ} \mathrm{C}$ selama 8 jam tidak memberikan pengaruh yang nyata terhadap perlakuan annealing $50^{\circ} \mathrm{C}, 8$ jam, dan perlakuan annealing $50{ }^{\circ} \mathrm{C}, 4$ jam tidak memberikan pengaruh yang nyata terhadap perlakuan annealing $50^{\circ} \mathrm{C}, 8$ jam.

Nilai viskositas balik pure kering ubi jalar menunjukan hasil yang cenderung mengalami peningkatan seiring dengan adanya perlakuan suhu dan lama annealing. Peningkatan nilai viskositas balik ini dikarenakan modifikasi annealing mengakibatkan pembentukan kompleks antar amilosa dan amilosa dengan amilopektin (Pertiwi, 2015), serta pembentukan double helix (Zavareze dan Dias, 2011) yang dapat meningkatkan kemampuan meretrogradasi. Viskositas balik menunjukkan kemampuan pati membentuk gel kembali setelah gelatinisasi dan menunjukkan kecenderungan pati untuk mengalami retrogradasi (Pranoto, dkk., 2014). Semakin tinggi viskositas balik, maka semakin tinggi pula kecepatan suspensi pati untuk retrogradasi sehingga terjadi peningkatan kekerasan gel (Klein, dkk., 2013).

\section{Kadar Air}

Berdasarkan hasil analisis statistik menunjukan bahwa perlakuan annealing berpengaruh nyata terhadap kadar air pure kering ubi jalar tanpa perlakuan annealing. Sedangkan perlakuan suhu dan waktu annealing tidak menunjukan pengaruh yang nyata terhadap kadar air. Hasil analisis kadar air pure kering ubi jalar pada Tabel 2.

Tabel 2. Pengaruh Annealing terhadap kadar Air Pure Kering Ubi Jalar

\begin{tabular}{crl}
\hline $\begin{array}{c}\text { Perlakuan } \\
\text { Annealing }\end{array}$ & Rata - Rata Perlakuan (\%) \\
\hline A & $5,728 \pm 0,506$ & a \\
B & $4,896 \pm 0,323$ & b \\
C & $4,711 \pm 0,563$ & b \\
D & $4,880 \pm 0,396$ & b \\
E & $4,784 \pm 0,323$ & b
\end{tabular}

Keterangan : Rata-rata perlakuan yang ditandai dengan huruf kecil yang sama tidak berbeda nyata pada taraf $5 \%$ menurut Uji Duncan

Kadar air pure kering ubi jalar menunjukan pengaruh yang berbeda nyata antara pure kering ubi jalar kontrol dan pure kering ubi jalar dengan perlakuan annealing, namun tidak memberikan pengaruh yang nyata antar perlakuan suhu dan lama annealing. Perlakuan annealing menyebabkan adanya penurunan nilai kadar air dibandingkan dengan tanpa perlakuan annealing. Penurunan kadar air pada pure kering ubi jalar dengan perlakuan annealing 
diakibatkan karena adanya penguapan air yang lebih tinggi selama pengeringan. Menurut Putri dan Zubaidah (2015), pengaruh suhu tinggi selama annealing menyebabkan granula pati terbuka lebih besar dan memungkinkan adanya penguapan air yang lebih tinggi selama pengeringan. Pati yang dimasukan kedalam air dapat menyerap air dan mengembang (membengkak) namun jumlah air yang terserap terbatas (Winarno, 2004). Pengembangan pati inilah yang menyebabkan penguapan air selama pengeringan semakin besar, seperti menurut Haryadi (1994) dikutip Putri dan Zubaidah
(2015) yang berpendapat bahwa membengkaknya granula pati menyebabkan rongga yang lebih besar sehingga penguapan air selama pengeringan semakin besar.

\section{Sifat Padatan (Solid Properties)}

Karakteristik padatan pure kering ubi jalar yang diamati meliputi kekerasan dan kelengketan yang diuji dengan menggunakan Texture Analyzer. Data karakteristik padatan dapat dilihat pada Tabel 3.

Tabel 3. Pengaruh Annealing terhadap Karakteristik Padatan Pure Kering Ubi Jalar

\begin{tabular}{ccc}
\hline \multirow{2}{*}{ Perlakuan Annealing } & \multicolumn{2}{c}{ Solid Properties dengan Texture Analyzer } \\
\cline { 2 - 3 } & Kelengketan (Adhesiveness) (gsec) & $\begin{array}{c}\text { Kekerasan } \\
\text { (Hardness) }(\mathrm{g})\end{array}$ \\
\hline A & $-72,524 \pm 1,223 \mathrm{a}$ & $72,66 \pm 1,777 \mathrm{a}$ \\
B & $-69,739 \pm 1,998 \mathrm{~b}$ & $79,58 \pm 0,498 \mathrm{~b}$ \\
C & $-68,432 \pm 0,757 \mathrm{~b}$ & $88,45 \pm 5,033 \mathrm{c}$ \\
D & $-69,774 \pm 0,972 \mathrm{~b}$ & $108,54 \pm 6,282 \mathrm{~d}$ \\
E & $-68,585 \pm 0,130 \mathrm{~b}$ & $87,44 \pm 3,594 \mathrm{c}$ \\
\hline
\end{tabular}

Keterangan : Rata-rata perlakuan yang ditandai dengan huruf kecil yang sama tidak berbeda nyata pada taraf $5 \%$ menurut Uji Duncan

\section{Kelengketan (Adhesiveness)}

Hasil analisis statistik menunjukan bahwa pure kering ubi jalar kontrol dan berbagai perlakuan annealing menunjukan pengaruh yang berbeda nyata, namun antar perlakuan annealing tidak memberikan pengaruh yang berbeda nyata. Semakin negatif nilai kelengketan, maka menunjukan bahwa sampel yang diuji memiliki sifat yang lebih lengket. Parameter kelengketan ini juga berhubungan dengan suhu awal gelatinisasi pure kering ubi jalar. Tekstur lengket diakibatkan oleh banyaknya granula pati yang rusak selama pengeringan. Pada proses pengeringan, granula pati akan mengalami kerusakan karena sifat alami pati yang tidak tahan panas. Pemanasan pati dengan suhu tinggi secara terus menerus dapat memutus ikatan amilosa dengan amilopektin. Amilopektin yang mudah menyerap air membentuk tekstur lengket pada saat direhidrasi (Histifarina, 2002). Pure kering ubi jalar yang telah mengalami proses annealing memiliki pati dengan kristalisitas yang lebih tinggi akibat perlakuan suhu yang diberikan (Sun, dkk., 2013). Hal inilah yang menyebabkan pati pada pure kering ubi jalar memiliki resistensi yang lebih tinggi terhadap perlakuan suhu sehingga semakin sedikit pati yang rusak ketika proses pengolahan pure kering ubi jalar.

\section{Kekerasan (Hardness)}

Hasil analisis statistik menunjukan bahwa kekerasan pure kering ubi jalar setelah rehidrasi menunjukan pengaruh yang berbeda nyata pada semua perlakuan. Hasil analisis menunjukan adanya kecenderungan peningkatan nilai kekerasan. Besarnya nilai kekerasan berhubungan dengan besarnya nilai setback yang menunjukkan kemampuan pati untuk beretrogradasi dan sineresis (Sandhu dan Singh, 2007). Semakin tinggi nilai viskositas setback, maka kekerasan pure kering ubi jalar setelah rehidrasi menjadi lebih tinggi. Nilai kekerasan pure ubi jalar juga berhubungan dengan kadar amilosa. Menurut Eliasson (2004), gel dengan 
amilosa yang tinggi akan lebih stabil terhadap pemanasan dan dapat membentuk gel dengan baik. Kadar amilosa yang tinggi dapat menyebabkan kemampuan teretrogadasi menjadi lebih tinggi (Salim dan Putri, 2015). Perlakuan annealing dapat menyebabkan terbentuknya struktur kristalin baru yang membuat pati pada ubi jalar lebih kokoh sehingga pati dapat dipertahankan termasuk ketika proses pemasakan (Haryadi, 2006),

\section{Karakteristik Organoleptik Warna}

Karakteristik organoleptik warna diamati secara hedonik pada pure kering ubi jaar yang telah di rehidrasi dengan air hangat. Data hasil uji organoleptik warna dapat dilihat pada Tabel 4.

Tabel 4. Pengaruh Annealing terhadap Uji Hedonik Warna Pure KeringUbi Jalar

\begin{tabular}{cl}
\hline Perlakuan & Rata - Rata Perlakuan \\
\hline Annealing & \\
\hline A & $2,556 \pm 0,814 \mathrm{a}$ \\
B & $3,578 \pm 1,109 \mathrm{~b}$ \\
C & $3,556 \pm 0,929 \mathrm{~b}$ \\
D & $3,311 \pm 0,730 \mathrm{bc}$ \\
E & $3,045 \pm 0,629 \mathrm{c}$ \\
\hline
\end{tabular}

Keterangan : Rata-rata perlakuan yang ditandai dengan huruf kecil yang sama tidak berbeda nyata pada taraf $5 \%$ menurut Uji Duncan

Hasil analisis statistik menunjukan bahwa pure ubi jalar kontrol memiliki pengaruh yang berbeda nyata pada semua perlakuan annealing. Perlakuan annealing dapat meningkatkan kesukaan panelis terhadap parameter warna. Kesukaan panelis terhadap warna dapat dipengaruhi oleh kecerahan pure kering ubi jalar setelah rehidrasi. Adanya pengaruh nyata akibat perlakuan annealing ini sejalan dengan penelitian Salim dan Putri (2015) yang menunjukan adanya kenaikan nilai kecerahan akibat perlakuan suhu dan lama annealing chips. Hal ini dikarenakan selama annealing terjadi penurunan fenol sehingga mampu menghambat reaksi pencoklatan. secara enzimatis. Menurut Kasuma, (2012) Fenol dapat larut dalam air dan rentan terhadap cahaya.

\section{Daya Rehidrasi}

Berdasarkan hasil analisis statistik, perlakuan annealing memberikan pengaruh nyata terhadap daya rehidrasi pure kering ubi jalar. Hasil analisis daya rehidrasi dapat dilihat pada Tabel 5.

Tabel 5. Pengaruh Annealing terhadap Daya Rehidrasi Pure Kering Ubi Jalar

\begin{tabular}{cc}
\hline Perlakuan Annealing & $\begin{array}{c}\text { Rata - Rata } \\
\text { Perlakuan }(\mathrm{ml} / \mathrm{g})\end{array}$ \\
\hline A & $4,237 \pm 0,156 \mathrm{a}$ \\
B & $3,329 \pm 0,377 \mathrm{a}$ \\
C & $3,549 \pm 0,297 \mathrm{a}$ \\
D & $3,216 \pm 0,237 \mathrm{a}$ \\
E & $3,030 \pm 0,237 \mathrm{~b}$ \\
\hline
\end{tabular}

Keterangan : Rata-rata perlakuan yang ditandai dengan huruf kecil yang sama tidak berbeda nyata pada taraf $5 \%$ menurut Uji Duncan

Hasil analisis statistik menunjukan bahwa berbagai perlakuan suhu dan lama annealing tidak memberikan pengaruh yang berbeda nyata terhadap nilai daya rehidrasi pure kering ubi jalar. Namun demikian, adanya perlakuan annealing memberikan pengaruh yang berbeda nyata terhadap pure kering ubi jalar tanpa perlakuan annealing. Hal ini diakibatkan karena perlakuan annealing dapat memperkuat sruktur kristalin pati sehingga menurunkan daya rehidrasi pure kering ub jalar.

Putri dan Zubaidah (2015) dalam penelitiannya menunjukan bahwa lama perendaman selama annealing diduga dapat mengakibatkan struktur pati yang merenggang dan menyebabkan adanya interaksi air dan panas. Panas yang diberikan selama annealing dapat menyebabkan struktur pati lebih menyerap air dan mengalami pembengkakan. Proses inilah yang mengakibatkan struktur kristalin pati semakin kuat dan akan lebih sulit ketika direhidrasi. Penurunan daya rehidrasi juga disebabkan oleh perubahan sifat kristalinitas pati sehingga mengurangi hidrasi air pada granula pati dan formasi kompleks amilolipid (Waduge, dkk, 2006).

\section{Rendemen}

Berdasarkan hasil analisis statistik, perlakuan annealing tidak memberikan 
pengaruh nyata terhadap rendemen pure kering ubi jalar. Hasil analisis rendemen dapat dilihat pada Tabel 6.

Tabel 6. Pengaruh Annealing terhadap Rendemen Pure Kering Ubi Jalar

\begin{tabular}{cc}
\hline $\begin{array}{c}\text { Perlakuan } \\
\text { Annealing }\end{array}$ & Rata -Rata Perlakuan (\%) \\
\hline A & $24,02 \pm 2,472 \mathrm{a}$ \\
B & $21,79 \pm 0,712 \mathrm{a}$ \\
C & $21,88 \pm 2,671 \mathrm{a}$ \\
D & $23,11 \pm 3,494 \mathrm{a}$ \\
E & $18,95 \pm 1,153 \mathrm{a}$ \\
\hline
\end{tabular}

Keterangan : Rata-rata perlakuan yang ditandai dengan huruf kecil yang sama tidak berbeda nyata pada taraf $5 \%$ menurut Uji Duncan

Hasil analisis menunjukan bahwa pengaruh annealing tidak berpengaruh nyata terhadap rendemen produk yang dihasilkan. Penggunaan bahan baku dengan karakteristik yang seragam serta proses pengeringan yang sama menyebabkan rendemen pure kering ubi jalar kontrol dan dengan perlakuan annealing tidak berbeda nyata. Menurut Chayati dkk (2008), rendemen tepung dipengaruhi oleh serat yang dalam bahan, semakin tinggi serat kasar dalam bahan yang sukar dihaluskan, maka semakin banyak yang tidak dapat lolos pada proses pengayakan dan mempengaruhi rendemen yang dihasilkan.

Pengamatan Kadar Abu, Kadar Protein, Kadar Lemak, dan Kadar Karbohidrat pada Pure Kering Ubi Jalar dengan Perlakuan Annealing $50{ }^{\circ} \mathrm{C}$ selama 4 jam.

Penentuan perlakuan terbaik menunjukan perlakuan kombinasi annealing suhu perendaman suhu $50^{\circ} \mathrm{C}$ selama 4 jam menghasilkan pure kering ubi jalar dengan karakteristik terbaik. Hasil analisis kadar air, kadar abu, kadar protein, dan kadar karbohidrat pure kering ubi jalar dengan perlakuan terbaik dapat dilihat pada Tabel 7 .

Hasil uji kadar abu pure kering ubi jalar menunjukan bahwa pure kering ubi jalar perlakuan $50{ }^{\circ} \mathrm{C}$ selama 4 jam memiliki kadar abu 0,76\%. Menurut Koswara, (2013), ubi jalar mengandung berbagai jenis mineral seperti kalsium (Ca), fosfor $(P)$, natrium $(\mathrm{Na})$, kalium $(\mathrm{K})$, sulfur $(\mathrm{S})$, besi $(\mathrm{Fe})$, dan seng $(Z n)$. Pure kering ubi jalar sebagai sediaan pangan darurat memerlukan mineral diantaranya natrium, kalium, klor, kalsium, fosfor, magnesium, kromium, tembaga, iodin, besi, mangan, selenium, dan seng. Hal tersebut menunjukan bahwa diperlukan fortifikasi beberapa mineral pada pure kering ubi jalar sebagai pangan darurat sehingga dapat memenuhi kebutuhan mineral yang sesuai standar yang ditetapkan oleh IOM. Kadar protein pure kering ubi jalar dengan perlakuan annealing pada suhu 50 ${ }^{\circ} \mathrm{C}$ selama 4 jam yaitu 1,76\%. Nilai kadar protein pure kering ubi jalar ini masih dibawah standar kandungan nutrisi dari emergency food product yang ditetapkan IOM (1995) dalam Zoumas, dkk (2002), yaitu sebesar $7,9 \mathrm{~g} / 50 \mathrm{~g}$ atau setara dengan $15,8 \%$. Pure kering ubi jalar sebagai sediaan emergency food product masih memerlukan penambahan sumber protein lain.

Tabel 7. Data Hasil Proksimat Pure Kering Ubi Jalar dengan Perlakuan Suhu dan Lama Annealing Terbaik

\begin{tabular}{lc}
\hline \multicolumn{1}{c}{ Pengamatan } & Nilai \\
\hline Kadar Abu & $0,76 \%$ \\
Kadar Protein & $1,76 \%$ \\
Kadar Lemak & $1,89 \%$ \\
Kadar Karbohidrat & $90,88 \%$ \\
\hline
\end{tabular}

Hasil uji kadar lemak pure kering ubi jalar dengan perlakuan annealing memiliki nilai $1,86 \%$. Nilai kadar lemak ini belum memenuhi standar kandungan nutrisi dari emergency food product yang ditetapkan IOM (1995) yaitu sebesar 9-12 g/50 g atau setara dengan 18-24\%. Penambahan sumber lemak yang dikombinasikan pada pure kering ubi jalar dapat meningkatkan kadar lemak produk sehingga dapat memenuhi standar yang ditetapkan.

Kadar karbohidrat menunjukan nilai $90,88 \%$. Nilai ini lebih tinggi dari standar kandungan nutrisi dari emergency food product yang ditetapkan IOM (1995) yaitu sebesar 23-35 g/50 g atau setara dengan 46-70\%. Penambahan sumber energi dalam bentuk protein ataupun lemak akan mempengaruhi komposisi produk sehingga dapat dihasilkan kadar karbohidrat yang sesuai dengan standar tersebut. 


\section{SIMPULAN}

Pure kering ubi jalar dengan berbagai perlakuan suhu dan lama annealing memberikan pengaruh yang nyata terhadap suhu awal gelatinisasi, viskositas puncak, viskositas jatuh, viskositas balik kadar air, kekerasan, kelengketan, kesukaan terhadap warna, serta nilai daya rehidrasi, tetapi tidak memberikan pengaruh nyata terhadap rendemen.

Perlakuan annealing pada suhu $50{ }^{\circ} \mathrm{C}$ selama 4 jam menghasilkan karakteristik terbaik dengan suhu awal gelatinisai 54,3 ${ }^{\circ} \mathrm{C}$; viskositas puncak 850,50 cP; viskositas breakdown 25,17 cP; viskositas setback 395 cP; kadar air 4,880\%, nilai hardness $108,535 \mathrm{~g}$; nilai adhesiveness $-69,773 \mathrm{gs}$, nilai kesukaan terhadap warna 3,331 (biasa); daya rehidrasi $3,216 \mathrm{~mL} / \mathrm{g}$, dan rendemen 23,107\%; serta memiliki kandungan protein 1,76\%; lemak 1,89\%; abu $0,76 \%$; dan karbohidrat $90,88 \%$.

Hasil penelitian pada berbagai parameter pengujian menunjukan bahwa pure kering ubi jalar dengan perlakuan annealing berpotensi diaplikasikan sebagai bahan sediaan emergency food product dalam bentuk pure kering ubi jalar siap konsumsi dengan cara direhidrasi serta dalam bentuk sup.

\section{SARAN}

Sebaiknya dilakukan kajian lebih lanjut untuk memperbaiki daya rehidrasi produk yang masi dibawah standar produk instan komersial. Selain itu, hasil analisis proksimat menunjukan nilai kadar protein dan lemak yang dibawah standar kandungan nutrisi EFP, sedangkan kadar karbohidrat lebih tinggi dibandingkan standar nutrisi EFP sehingga diperlukan kajian lebih lanjut mengenai kombinasi pure kering ubi jalar dengan sumber protein dan sumber lemak lainnya.

\section{DAFTAR PUSTAKA}

Adebowale, K. O., B. I. Olu-Owolabi, O. O. Olayinka, and O. S. Lawal. 2005. Effect of Heat Moisture Treatment and Annealing On Physicochemical Properties of Red Sorghum Strach. African Jurnal Of Biotechnol. 4(9) : 928933.
Chayati I, Handayani THW, Nugraheni M, dan Ratnaningsih N. 2008. Teknologi Pengolahan Pati Garut dan Diversifikasi Produk Olahannya Dalam Rangka Peningkatan Ketahanan Pangan. Jurusan Pendidikan Teknik Boga dan Busana. Fakultas Teknik Universitas Negeri Yogyakarta. Yogyakarta.

Collado, L. S. and H. Corke. 1999. Heat Moisture Treatment Effect On Sweet Potato Starches Differing In Amylosa Content. Food Cherm 65 (3): 339-346.

Depdikbud. 1996. Kamus Besar bahasa Indonesia. Jakarta: Balai Pustaka

Djuwardi, A. 2009. Cassava: Solusi Pemberagaman Kemandirian Pangan. Jakarta: Grasindo

Eliasson, A. C. 2004. Starch in Food: Structure, Function, and Application. CRC Press. North America

Haryadi. 2006. Teknologi Pengolahan Beras. UGM Press. Yogyakarta

Histifarina, D. 2002. Kajian Pembuatan Kentang Tumbuk Instan dan Stabilitasnya Selama Penyimpanan. Tesis. Program Pascasarjana Institut Pertanian Bogor. Bogor.

Honestin, T. 2007. Karakterisasi Tepung Ubi Jalar (Ipomoea batatas). Skripsi. Departemen IImu dan Teknologi Pangan, Fakultas Teknologi Pertanian, Institut Pertanian Bogor.

Kasuma, N.Y. 2012. Degradasi Senyawa Fenol Pada Limbah Rumah Sakit Secara Fotosintesis dengan Bantuan Katalis Tio. Pasca Sarjana Unand. Padang

Klein, B., Pinto, V.Z., Vanier, N.L.., Zavareze., E.R., Colussi., R., Evangelho, J.A., Gutkosko, L.C, and Dias, A.R.G. 2013. Effect of single and dual heat-moisture treatments on properties ofrice, cassava, and pinhao starches. Carbohydrate Polymers 98, 1578-1584

Koswara, S. 2009. Teknologi Modifikasi Pati. EbookPangan. Available online at tekpan.unimus.ac.id. Diakses pada tanggal 3 Februari 2016.

Koswara, S. 2013. Teknologi Pengolahan Umbi-umbian. Bogor: Southeast Asian Food And Agricultural Science and Technology (SEAFAST) Center 
Research and Community Service Institution. Bogor Agricultural University.

Kusnandar, F. 2010. 2010. Teknologi Modifikasi Pati dan Aplikasinya di Industri Pangan. A review. Departemen Ilmu Teknologi Pangan, Institut Pertanian Bogor, Bogor

Nahari, I. R. S. 2016. Skripsi Pengaruh Lama Perendaman Dan Konsentrasi $\mathrm{Na}_{5} \mathrm{P}_{3} \mathrm{O}_{10}$ Terhadap Karakteristik Fisik Dan KimiaMashed Ubi Jalar Instan

Oktavianti, V. C. dan Putri, W. D. R. 2015. Pengaruh Modifikasi Fisik Annealing Terhadap KarakteristikTepung Ubi Jalar Ungu Varietas Ayamurasaki. Jurnal Pangan dan Agroindustri Vol. 3 No 2 p.551-559

Pertiwi A. 2015. Sifat Fungsional dan Amilografi Pati Millet Putih (Pennisetum glaucum) Termodifikasi secara Heat Moisture Treatment dan Annealing. Skripsi. Fakultas Teknologi Industri Pertanian, Universitas Padjadjaran. Sumedang.

Pranoto, Y., Rahmayuni, Haryadi and Rakshit, S. K. 2014. Physicochemical properties of heat moisture treated sweet potato starches of selected Indonesian varieties. International Food Research Journal 21(5): 2031-2038

Putri, W. D. R dan Zubaidah, E. 2015. Karakteristik Fungsional Tepung Sukun Hasil Modifikasi Annealing. JournalProsiding Seminar Agroindustri dan Lokakarya Nasional FKPT-TPI. ISBN:978-602-7998-92-6

Salim, A. R dan Putri, W. D. R. 2015. Pengaruh Suhu dan Lama AnnealingTerhadap Sifat FisikKimiaTepung Ubi Jalar Putih Varietas Manohara. Jurnal Pangan dan Agroindustri Vol. 3 No 2 p.602-609

Sandhu, K. S., and Singh, N. 2007. Some properties of corn starches II: physicochemical, gelatinization, retrogradation, pasting and gel textural properties. Food Chemistry, 101, 14991507.

Santoso, B. 2010. Karakterisasi sensori, fungsional dan komposisi gizi ubijalar lokal unggulan asal dataran tinggi Wamena, serta kajian formulasi Mashed Sweet Potato. Laporan Penelitian Dikti. Jakarta: Universitas Indonesia
Sun, Q., Wang, T., Xiong, L., Zhao. Y. 2013. The effect of heat moisture treatment on physicochemical properties of early indica rice. Food Chemistry 141, 853857

Waduge, R. N., Hoover, R., R., Vasanthan, T., Gao, J., dan Li, J. 2006. Effect of annealing on the structure and physicochemical properties of barley starch of varying amylose content, Food Res. Int 39:35-77

Winarno, F. G., 2004. Kimia Pangan dan Gizi. PT Gramedia Pustaka Utama. Jakarta

Zavareze, E. R., and Dias, A. R. G. 2011. Impact of heat-moisture treatment and annealing in starches: A review. Carbohydrate Polymers, 83, 317-328.

Zoumas B. L., L. E. Armstrong., J. R Backstrand., W. L. Chenoweth., P. Chinachoti., B. P. Klein., H. W. Lane., K. S. Marsh., M. Tolvanen. 2002. HighEnergy, Nutrient-Dense Emergency Relief Product. Food and Nutrition Board: Institute of Medicine. National Academy Press, Washington, DC. 